\title{
International Collaboration in the Study of European Migration to the United States
}

\section{Rudolph J. Vecoli}

\author{
University of Minnesota
}

This is a report on five weeks of travel in 1977 in Finland, Poland Czechoslovakia, Hungary, Romania, Yugoslavia, and Italy, which was under. taken in order to initiate and develop exchanges, joint research, and new form: of academic collaboration between the Immigration History Research Cente and its counterparts in those countries. The travel was funded by grants from the U.S. Department of State and the University of Minnesota's Office of International Programs.

The Immigration History Research Center (IHRC) has for more than : decade encouraged and facilitated scholarly research on those American ethnis groups whose origins are to be found in eastern and southern Europear countries. Research collections have been developed which document the pro cesses of migration and adjustment of the twenty-four immigrant groups en compassed by the Center. The study of the trans-Atlantic migration must, $o$ course, be concerned with backgrounds and causes as well as destinations anc consequences. The subject, therefore, is one of inherent interest to scholars i the countries of emigration. This common interest creates natural links be tween American scholars and their European colleagues, an interest whicl spans the disciplines of the humanities and social sciences.

In recent years there has been a remarkable upsurge of interest in th study of the "American" migrations in eastern and southern Europe. Research institutes and projects have been established in Turku, Cracow, Prague Bratislava, Budapest, Zagreb, Ljublijana, Rome, and Florence. The IHRC has engaged in a variety of cooperative projects with these institutions, includ ing the exchange of research materials and scholars and the joint sponsorshil of conferences and publications.

Encouraged by these fruitful ventures, I undertook this trip to expanc further such cooperative relationships. Specifically in my discussions witt directors, scholars, librarians, and archivists, I addressed myself to the follow. ing topics:

a) promotion of exchanges of students and scholars;

b) cooperative research, bibliographical and publication projects; 
c) cooperative projects for microfilming archival materials and publications;

d) continuing exchanges of publications and research materials;

e) bilateral and multi-national conferences dealing with aspects of the eastern and southern European immigration.

There follows a summary report of these discussions. For further information on any aspect of this report, inquire of Rudolph J. Vecoli, Director, Immigration History Research Center, 826 Berry Street, St. Paul, Minnesota 55114.

\section{June 19-22: Finland}

TURKU: Since Professor Vilho Niitemaa, Professor of General History, at the University of Turku was seriously ill, I met with his colleagues: Dr. Olavi Koivukangas, Director, Institute of Migration, Dr. Reino Kero and Professor Keijo Virtanen of the Institute of General History. Summary of discussions: Research on the Finnish emigration has been carried on for some years at the Institute of General History (IGH) with some 20 M.A. theses and 5 doctoral dissertations produced. The IGH has collected much research material both in the original and on microfilm, such as passport and passenger lists, oral interviews, questionnaires and newspapers. Since its establishment in 1974, the Institute of Migration has published some ten books on Finnish migration. It will soon issue a general bibliography on the subject. Recommendations: We placed a high priority on a general guide to sources for Finnish American immigration and agreed to explore the possibility of the preparation of such a guide as a joint project. We also agreed to initiate discussions regarding a conference on the Finnish migration experience in a comparative perspective (Australian, Canadian, Swedish, American).

HELSINKI: Meetings with Ms. Leena Petill, Acquisitions Librarian, Helsinki University Library, to review exchanges of Finnish American newspapers on microfilm between the IHRC and the Helsinki University Library (HUL); at the National Archives of Finland with Mr. Jussi Kausanmäki and staff to examine holdings pertaining to the Finnish emigration (studies made by provincial governors of causes of emigration, records of returned emigrants, etc.). Visit to Finnish Literature Society (includes Folklore Archives which holds tapes of folk tales and music collected among Finnish immigrants in America). Meetings with Mrs. Kaija Kallinen, Scholarship Centre, Department for International Relations, Ministry of Education, to discuss possibilities for scholarships for American students, and with Mr. Tauri Aaltio, Director of Suomi-Seura (Suomi Society) regarding its cultural program. (The Suomi Society has made financial contributions in support of the IHRC's Finnish American Research Fund). Visit with Mr. Mark Glago, American Center, USIS, regarding possible support of exchanges in migration studies.

June 22-28: Poland

WARSAW: Meetings at Polish National Library with Dr. Witold Stankiewicz, Director, and members of his staff, including department heads (Wolosz, Klossowski, Piber, and Kaminski). Summary of discussions: The 
National Library is engaged in an ongoing bibliographical guide to materials on Polonia; also a survey of the National Archives for pertinent documentation has been initiated; a Union Catalogue on Polish Periodicals Abroad is planned. On behalf of the National Library and the Research Group for the History of Polish Emigrants of the Institute of History, Polish Academy of Sciences, Dr. Stankiewicz warmly endorsed the idea of cooperating with the IHRC. Recommendations: We agreed to send bibliographical information regarding our respective holdings leading to exchanges of both microfilms and publications.

North American Studies Seminar of Professor M. Drozdowski, Institute of History, Polish Academy of Sciences: I presented a description of the current state of immigration studies in the U.S. and of the work of the IHRC. Drozdowski described the seminar research in progress and expressed a strong interest in developing exchanges between the Institute of History and the IHRC.

CRACOW: Meetings with members of the Polonia Institute: Professors Grzegorz Babinski, Miroslaw Francic, Gwidon Rysiak, Deputy Director (The Director, Professor Hieronim Kubiak was then in the United States), and other staff and students. The Polonia Institute, established in 1976 to conduc1 research specifically on Poles in America, is composed of four branches (Law, Sociology, History and Literature). It is a unit of the Jagiellonian University and has some twenty staff members. A 1975 conference on Polonia the proceedings of which have been published led to the founding of the Institute. This will probably be the most important Polish center of research on Poles in America, although there are other projects underway at the Catholic University at Lublin, Marie Curie University of Lublin, and the University of Poznan. I met the Rector of the Jagiellonian University who expressed a personal interest in the work of the IHRC; gave a lecture to the Institute seminar; attended a reception at the home of American Consul, Mr. Peter T. Becskehazy. Summary of discussions: The Polonia Institute is in initial stages of developing research programs, but has ambitious plans for studies and publications in the field. It publishes the journal, Preglad Polonijny (Polonia Review). A bibliography on Polish American immigration (1865-1975) is in preparation. Recommendations: Exchanges of publications, including microfilms, between the Polonia Institute (including holdings of University Library) and the IHRC were agreed upon. Also the Polonia Institute desires tc send additional students to work in the IHRC collections (several have already done so) and is willing to provide scholarships to American students coming tc work in Cracow.

\section{June 28-July 3: Czechoslovakia}

PRAGUE: Meetings at the Naprstek Museum with Dr. Vladimi Zharadnicek, Director; Dr. Jan Polisensky, historian; and Dr. A. Robek, Director of the Institute of Ethnography, Czechoslovak Academy of Sciences. Summary of discussions: The Naprstek Museum has extensive materials or. Czechs in America, including rare files of publications and correspondence. Other archival holdings of Czech-American documents include the Staatsachiv in Prague, e.g., police files on emigration, the periodical collection in the National Museum, and regional and district archives. A guide to these scattered materials is being prepared. Among works in progress is a volume or ethnic processes among Czechs in North America, also a volume of correspon- 
dence of Czech Americans, and finally a bibliography of works on Czech Americans. Yet it was said that there is not a great deal of interest among historians in the study of the Czech immigration at present. The Institute of Ethnography includes in its scope the study of migration in general and of Czech immigration in particular. Recommendations: Exchanges of bibliographical guides and of publications may be initiated without formal agreement (exchanges, however, must be limited to materials published prior to 1930 or dealing with that period); however, other forms of cooperation, e.g., exchanges of students will require the approval of the Academy of Sciences and Ministry of Culture.

BRATISLAVA: Meetings at Matica Slovenská with Dr. Ján Sirácky, Director; Dr. Frantisek Bielek, Research Director, and Elena Jakešová of the Institute of History who is writing a dissertation on Slovaks in Canada. Summary of discussions: Matica Slovenská has research group collective working on the study of Slovak emigration. A two volume work on the subject is in preparation; in addition, several volumes of documents on the Slovaks in America are to be published. The Matica Slovenská is planning a symposium for two years hence on the theoretical aspects of migration. Recommendations: There is a need for exchanges of scholarly literature: recent American works and journals are not available. Exchanges of scholars or staff are not possible at this time. American students, however, may attend the Studia Academica Slovakia at the University of Bratislava during the summer.

\section{July 3-5: Hungary}

BUDAPEST: Meeting at the Institute for Cultural Relations with Dr. Endre Polgár regarding the possibilities for exchanges of scholars.

Meetings at Institute of History, Hungarian Academy of Sciences, with Dr. Ferenc Mucsi, Department of Modern History, and Miklós Incze, Head, Department of Historical Information, and staff members. Summary of discussion: Agreement in principle on exchanges of materials between IHRC and Institute of History Library (their interest extends to all central European ethnic groups). The Library holds reports of government investigations of emigration, also other studies regarding the emigration.

Meeting at the Szechenyi National Library with Dr. Jozsef Vekerdi, Head, International Exchanges; the Library wishes to continue exchanges with IHRC; it can supply microfilms of holdings of Hungarian, Slovak and Ruthenian American newspapers.

Meetings with Dr. Julianna Puskas, Institute of History, and Dr. Jozsef Kovacs, Institute of Literary History, regarding migration research in Hungary (these are the two leading scholars who have studied the Hungarians in America). Kovacs is preparing a bibliography of articles in some thirty Hungarian American newspapers.

July 5-8: Romania

BUCHAREST: Meetings at the Romania Association with Petre Ghelmez, editor of Tribuna României; Mr. Radu Toma of AGERPRESS, and Mr. Mircea Avrarm, Librarian of the Biblioteca Astra. Unfortunately the Secretary of the Association, Dr. Virgil Cândea, was ill; however, in a telephone conversation, he expressed an eagerness to institute exchanges of students of the Romanian migration. Mr. Toma is preparing a dissertation at the 
University of Bucharest on the Romanians in America. Summary of discussion: The Romania Association maintains cultural contacts with Romanians abroad, publishes the Tribuna, and other materials for the teaching of the Romanian language and culture. It is also initiating a research program and welcomes cooperative relations with the IHRC. A bibliography on Romanian emigration prepared by $\mathrm{Mr}$. Toma is to be published by the Association.

Meeting at Biblioteca Academiei Romane with Dr. Gavril Strempel, Director; Ms. Alice Sterescu, Head of Exchange Department; and Mr. Toma. Summary of discussion: The Library is interested in an exchange program, in receiving both Romanian American and general American publications; they lack Romanian American newspapers for the period after 1940. We agreed on exchanges of bibliographical information and materials.

Meeting at Nicolae Iorga Institute of History with Dr. Dan Berindei, Vice-president of the Scientific Council; Dr. Cornelia Bodea, Mr. Toma and Dr. Ion Stanciu, Vice Director of the Institute. Discussion: Desire to establish institutional exchanges between the IHRC and NIIH expressed; publications of Institute offered in exchange.

Meeting at National Archives of Romania with Deputy Director General V. Arimia and staff. Summary of discussions: The holdings of Archives relevant to the emigration were described; include passports, records of diplomatic missions, and church archives; the most important collection is the loan Podea Papers (he was the most important leader of the Romanian Americans prior to World War I).

\section{July 8-16: Yugoslavia}

BELGRADE: Meetings at Matica Iseljenika Srbije (arranged by Dr. Koča Jončič, President) with Dr. Jončič, Mr. Bogdan Knezevic, Secretary of the Matica Iseljenika Srbije; Ms. Ksenija Gasinovic, Institute for International Scientific, Cultural, and Technical Collaboration for Serbia; Dr. Vladimir Grecić, Director at the Center for Regional Studies; Dr. Slobodan Zecevic, Director of the Institute of Ethnography, Dr. Duśan Drljača, also of the Institute; Dr. Nikola Petrovic, President of the Committee for the History of the Colonization of the Yugoslav Countries; Mr. Milorad Najdonovic, Assistant Manager of the National Library of Serbia, and Ms. Dragana Sreckovic, journalist of the Matica Iseljenika Srbije. Summary of discussion: I made a presentation on immigration studies in the U.S. and on the work of the IHRC. Each of the other participants described the activities of his or her particular institution as it related to the Serbian emigration. The Institute of Ethnography is initiating a project for the study of Serbian immigrants throughout the world, beginning with studies of the ethnographical backgrounds of the emigrants. Dr. Zecevic expressed a willingness to develop cooperative research project.

Visit to National Library of Serbia with Mr. Vladimir Stevanovic, Manager, Ms. Desanka Stamatovic, Deputy Director, and Mr. Jajdonovic. Summary of discussion: The National Library collects all materials on Serbia and Yugoslavia and is interested in having materials pertaining to Serbs in America. Although the Library was totally destroyed during World War II the collections have been substantially rebuilt. There are six National Libraries in Yugoslavia, all of which are interested in Yugoslav American materials. Exchanges of duplicates and of emigration materials which can be photocopied were proposed by the Library Director. Other archives which would be useful 
for migration studies would be the Archives of the Serbian Orthodox Church in Belgrade and the archives of the Matica Srbska in Novi Sad.

ZAGREB: Meetings at Matica Iseljenika Havartske with Dr. Ivan Cižmić, Dr. Tihomir Telisman, Director of the Zavod za Migracije; Dr. Mirko Valentic, Institute of History; Dr. Ivan Markovic, Librarian; Dr. Mirjana Domini, Political Scientist; and other members of the ZZM research group. Summary of discussions: The Library of Matica Iseljenika Havartske is a specialized collection on Croatian emigration; a bibliography of its holdings has been published. However, it lacks basic works in immigration and ethnicity. The MIH archival holdings includes the records of the Iseljenicki Komesarijat for the interwar period, also the archives of the Yugoslav Committee of National Defense in South America for the World War I period. We agreed to continue exchanges which had previously been established between the IHRC and MIH. Also we will encourage further exchanges of scholars (Dr. Cižmić has visited the IHRC several times for extended periods).

Meeting at Center for Migration Studies (the Director, Dr. Baucic was away on vacation) with Dr. Ante Bartulica, Assistant Director; Dr. Mladen Vedris, and other staff. The Center for Migration Studies is primarily concerned with analyses of the contemporary Yugoslav migrations.

$L J U B L J A N A$ : Meeting at the Institute of History, Slovenian Academy of Sciences, with Dr. Fran Zwitter, Historian; Professor Vladimir Klemencic, Director, Institute of Geography of the University of Ljubljana; Mr. Logar of the University Library, and Mrs. Homek of the State Archives of Slovenia. Summary of discussion: A Center for the Study of Slovenian Emigration had been established in 1963; a certain amount of work was accomplished, bibliographies of Slovenian immigrant publications compiled and documents in the State Archives surveyed. However, the project was suspended because of lack of funds. Now, with the interest and support of Professor Klemencic it will be revived. Copies of bibliographies will be made available to the IHRC. Since the State Archives are being moved to a new building there is no possibility of making microfilms for the next five years. The archives of the Slovenska Iseljenika Matica contain much pertinent documentation.

Meeting at National and University Library with Dr. Branko Berčić, Director; and staff. Summary of discussion: Bibliographical guides to Slovenian publications, including those issued in U.S.A. have been prepared. Copies of recent bibliographies were provided. The Library holds files of Slovenian American newspapers such as Glas Narod; it has facilities for making microfilms. We agreed in principle to continue the exchanges between the IHRC and the Library which have already been initiated.

July 16-22: Italy

ROME: Meetings at Centro Studi Emigrazione with Dr. Gianfausto Rosoli, Director, Dr. Maria Rosario Ostuni, Archivist, and Dr. Lidio Tomasi. Summary of discussion: Review of current research projects of the CSE; description of archival inventories being prepared of the archives of the Ministry of Foreign Affairs; agreement to continue exchanges between the IHRC and the CSE.

Conversations with Professors Renzo De Felice, Michael Lacko, Franco Cerase, and Malcolm Sylvers regarding the IHRC and their research interests in the Italian immigration, including the possibility of visits to the Center. 
FLORENCE: Meeting with Professor Giorgio Spini, President of the Committee for the Coordination of Studies of American History, who expressed strong support for further cooperative work on the Italian immigration and endorsed exchanges in this field.

Conversations with Professors Tomaso Detti, Anna Martellone and Adrianna Dádá regarding current research being done in Italy regarding the Italians in America. Summary of discussions: Positive interest in expanding research opportunities through exchanges expressed. Also the difficulty of keeping up with the American monographic literature on the part of Italian scholars was identified as a major problem. The provision of some vehicle to facilitate communication regarding current research and publication was strongly endorsed. 